\title{
Role of blood transfusion in saving mothers
}

\section{Manjit K. Mohi, Sangeeta Aggarwal*, Satinder Pal Khurana}

Department of Obstetrics and Gynecology, Government Medical College Patiala, Punjab, India

Received: 02 March 2020

Accepted: 30 March 2020

\section{*Correspondence:}

Dr. Sangeeta Aggarwal,

E-mail: drsangeetaaggrawal@gmail.com

Copyright: (c) the author(s), publisher and licensee Medip Academy. This is an open-access article distributed under the terms of the Creative Commons Attribution Non-Commercial License, which permits unrestricted non-commercial use, distribution, and reproduction in any medium, provided the original work is properly cited.

\section{ABSTRACT}

Background: Blood transfusion is recognised as one of the eight essential components of the comprehensive emergency obstetric care module which has been designed to reduce maternal morbidity and mortality rates after major obstetric hemorrhage and anemia.

Methods: This is a prospective observational study conducted between April1, 2016 to September 30, 2018 in department of obstetrics and gynecology, Government Medical College, Patiala. The MNM cases given transfusion were analysed in respect of number of antenatal visits, type of admission, distance of place of first referral unit from tertiary health care facility, amount of blood transfused, indications of blood transfusion, causes of haemorrhage and intervention performed.

Results: During this period, there were 123 cases of MNM, 90 patients required blood transfusion and were considered in this study. Maximum number of cases (94.45\%) were between 20-35 years of age. Majority of cases were primipara $(52.22 \%) .47 .77 \%$ cases were in $3^{\text {rd }}$ trimester, $33.33 \%$ postnatal cases and $16.66 \%$ cases were in first trimester. $88.88 \%$ cases requiring transfusion belong to low socioeconomic status. There was no antenatal visit in $80 \%$ cases who required blood transfusion. $78.8 \%$ patients required more than 4packed red cell transfusions. Haemorrhage was the indication in $60 \%$ cases for blood transfusion and anaemia in $40 \%$ cases. Postpartum haemorrhage $(28.4 \%)$ was most common indication for blood transfusion followed by ruptured ectopic pregnancy $(27.77 \%)$, antepartum haemorrhage $(11.11 \%)$, rupture uterus $(7.4 \%)$, rectus sheath hematoma $(5.55 \%)$, placenta accreta $(5.55 \%)$ and inversion uterus (3.7\%). Surgical interventions were performed in 51 cases.

Conclusions: Prevention and timely treatment of anaemia must receive attention by more active participation in term of antenatal check-ups. Skilled management of patients at the first referral units is advocated. There should be familiarity with the local protocol of relevant members of staff for management of massive hemorrhage. All major hemorrhages should be reviewed to ensure that there is no delay in provision of blood products.

Keywords: Blood transfusion, Maternal near miss, Obstetric haemorrhage

\section{INTRODUCTION}

Blood transfusion is recognised as one of the eight essential components of the comprehensive emergency obstetric care module which has been designed to reduce maternal mortality rates. Postpartum haemorrhage is a major contributor which accounts for $25 \%$ of all pregnancy-related deaths. ${ }^{1}$ While indications for transfusion in obstetrics may be emergent as well as nonemergent, the keystone of transfusion practice is that it should be appropriate that is, not given when not required and not missed when required. Transfusion is necessary if $\mathrm{Hb}<6 \mathrm{~g} / \mathrm{dl}$ and there are $<4$ weeks for delivery. When $\mathrm{Hb}$ is $<7 \mathrm{~g} / \mathrm{dl}$ in labour or in immediate postpartum period, blood transfusion is only indicated if there is previous history of bleeding or patient is prone for bleeding due to some medical condition. Transfusion is also indicated if $\mathrm{Hb}$ is $7 \mathrm{~g} / \mathrm{dl}$, for women with continued bleeding or at risk of further significant haemorrhage or for those presenting with severe 
symptoms that need immediate correction (cardiac decompensation). ${ }^{2,3}$ Anaemia during pregnancy is responsible for $15 \%$ of maternal mortality. Early correction of anaemia avoids the need for transfusion and reduces maternal mortality. Obstetric haemorrhage continues to be the leading cause of maternal mortality, ranging from $13 \%$ in developed countries to $34 \%$ in Africa. $^{4}$

An obstetric haemorrhage may occur before or after delivery, but $>80 \%$ of cases occur postpartum, responsible for $25 \%$ of the estimated 358,000 maternal deaths each year. ${ }^{5}$ Visual assessment of blood loss is "notoriously" inaccurate and clinicians can underestimate blood loss by 50\%. ${ }^{6}$ Definitions of massive haemorrhage vary and have limited value. It may arbitrarily be considered a situation where 1-1.5 blood volumes may need to be transfused acutely or in a 24-hours period where, normal blood volume in the adult is taken as approximately $7 \%$ of ideal body weight. ${ }^{7}$ Other definitions include $50 \%$ blood volume loss within 3hours or a rate of loss of $150 \mathrm{ml} / \mathrm{min}$. The common goals for transfusion in the obstetric patient is to achieve haemoglobin >8 g/dl, platelet count $>75 \times 109 / 1$, prothrombin time $(\mathrm{PT})<1.5 \times$ mean control, activated PT $<1.5 \times$ mean control and fibrinogen $>1.0 \mathrm{~g} / \mathrm{l}^{8}$ Economically deprived, illiterate people with insufficient antenatal care were more likely to suffer severe acute maternal morbidity. Delays in recognizing and treating hemorrhage frequently lead to inadequate blood product replacement and concomitant development of disseminated intravascular coagulation (DIC).

\section{Aims and objectives}

- To study importance of socioeconomic factors in maternal near miss patients of hemorrhage and anemia.

- To study role of antenatal care in maternal near miss cases requiring blood transfusion.

- To analyse indications of blood transfusion in maternal near miss cases.

- To analyse the importance of the distance from which the maternal near miss cases requiring blood transfusion were referred.

- To analyse the causes of haemorrhage and interventions performed to manage these cases.

\section{METHODS}

This is a prospective observational study of maternal near miss (MNM) cases requiring blood transfusion, conducted between April 1, 2016 to September 30, 2018 in department of obstetrics and gynecology, Government Medical College, Patiala, Punjab, India.

A maternal near miss is defined by WHO as a woman who nearly died but survived a complication that occurred during pregnancy, childbirth or within 42 days of termination of pregnancy.

\section{WHO near miss criteria 2011 include}

\section{Cardiovascular dysfunction}

Shock, cardiac arrest (absence of pulse/heart beat and loss of consciousness), use of continuous vasoactive drugs, cardiopulmonary resuscitation, severe hypoperfusion (lactate $>5 \mathrm{mmol} / \mathrm{l}$ or $>45 \mathrm{mg} / \mathrm{dl}$ ), severe acidosis $(\mathrm{pH}<7.1)$.

\section{Respiratory dysfunction}

Acute cyanosis, gasping, severe tachypnea (respiratory rate $>40$ breaths per minute), severe bradypnea (respiratory rate $<6$ breaths per minute), intubation and ventilation not related to anesthesia, severe hypoxemia (Oxygen saturation $<90 \%$ for $\geq 60$ minutes or $\mathrm{PAO}_{2} / \mathrm{FIO}_{2}$ $<200)$.

\section{Renal dysfunction}

Oliguria non-responsive to fluids or diuretics, dialysis for acute renal failure, severe acute azotemia (creatinine $\geq 300 \mu \mathrm{mol} / \mathrm{ml}$ or $\geq 3.5 \mathrm{mg} / \mathrm{dl})$.

\section{Coagulation/hematological dysfunction}

Failure to form clots, massive transfusion of blood or red cells ( $\geq 5$ units), severe acute thrombocytopenia $(<50,000$ platelets/ml) Hepatic dysfunction - Jaundice in the presence of pre-eclampsia, severe acute hyperbilirubinemia (bilirubin $>100 \mu \mathrm{mol} / \mathrm{l}$ or $>6.0$ $\mathrm{mg} / \mathrm{dl})$.

\section{Neurological dysfunction}

Prolonged unconsciousness (lasting $\geq 12$ hours)/coma (including metabolic coma), stroke, uncontrollable fits/status epilepticus, total paralysis.

\section{Uterine dysfunction}

Uterine haemorrhage or infection leading to hysterectomy.

\section{Inclusion criteria}

- Maternal near miss cases as per WHO criteria requiring blood transfusion were included in this study.

\section{Exclusion criteria}

- MNM cases who were not given blood transfusion were excluded from the study population.

The MNM cases were analysed in respect of their age, parity, gestational age, socioeconomic status, number of antenatal visits, type of admission, distance of place of first referral unit from tertiary health care facility, amount 
of blood transfusion given, indications of blood transfusion, incidence of haemorrhage according to obstetric period, causes of haemorrhage and intervention performed.

\section{RESULTS}

During April 01, 2016 to September 30, 2018 there were 6166 total deliveries, 5461 live births, 50 maternal deaths and $123 \mathrm{MNM}$ cases according to WHO criteria. Out of 123 maternal near miss cases, 90 patients were given blood transfusion.

Table 1: Inclusion of cases.

\begin{tabular}{|lll|}
\hline Maternal near miss & No. of patients & Percentage \\
\hline Total & 123 & - \\
\hline $\begin{array}{l}\text { Required blood } \\
\text { transfusion }\end{array}$ & 90 & $73.17 \%$ \\
\hline
\end{tabular}

The patients requiring blood transfusion in the present study were $73.17 \%$ out of total 123 maternal near miss cases (Table 1).

Table 2: Age wise distribution of cases.

\begin{tabular}{|lll|}
\hline Age & Number $(\mathbf{N}=90)$ & Percentage \\
\hline$<20$ years & 01 & $1.11 \%$ \\
\hline 20-35 years & 85 & $94.45 \%$ \\
\hline$>$ 35 years & 4 & $4.44 \%$ \\
\hline
\end{tabular}

Maximum number of cases $(94.45 \%)$ requiring blood transfusion were between 20-35 years of age only 1 patient was of less than 20 years of age and 4 patients were of more than 35years of age (Table 2).

Table 3: Parity distribution of cases.

\begin{tabular}{|lll|}
\hline Parity & Number $(\mathbf{N}=90)$ & Percentage \\
\hline Primipara & 47 & $52.22 \%$ \\
\hline Multipara & 43 & $47.78 \%$ \\
\hline
\end{tabular}

A total $47(52.22 \%)$ of cases were primipara and 43 $(47.78 \%)$ were multipara (Table 3$)$.

Table 4: Distribution according to gestational age.

\begin{tabular}{|lll|}
\hline Gestational age & Number $(\mathbf{N}=90)$ & Percentage \\
\hline$<13$ weeks & 15 & $16.66 \%$ \\
\hline $13-28$ weeks & 02 & $2.22 \%$ \\
\hline$>28$ weeks & 43 & $47.77 \%$ \\
\hline Postnatal & 30 & $33.33 \%$ \\
\hline
\end{tabular}

A total $47.77 \%$ cases were in $3^{\text {rd }}$ trimester and $33.33 \%$ were postnatal cases and $16.66 \%$ cases were in first trimester. There were only 2 cases in second trimester (Table 4). A total $80 \mathrm{MNM}$ cases i.e. $88.88 \%$ requiring transfusion belong to lower or lower middle socioeconomic class according to Kuppuswamy scale. 10 patients $(11.11 \%)$ were belonging to upper middle class (Table 5).

Table 5: Distribution according to socioeconomic class.

\begin{tabular}{|ll|l|}
\hline Class & Number $(\mathbf{N}=90)$ & Percentage \\
\hline Lower & 67 & $74.44 \%$ \\
\hline Lower middle & 13 & $14.44 \%$ \\
\hline Upper Middle & 10 & $11.11 \%$ \\
\hline
\end{tabular}

In $72(80 \%)$ cases, there was no history of any antenatal visit and $8.9 \%$ cases had only 1 or 2 antenatal check-ups and only 8 cases had history of more than 3 antenatal visits (Table 6).

Table 6: Distribution of cases as per number of antenatal visits.

\begin{tabular}{|lll|}
\hline $\begin{array}{l}\text { No. of antenatal } \\
\text { visits }\end{array}$ & $\begin{array}{l}\text { No. of patients } \\
(\mathbf{N}=90)\end{array}$ & Percentage \\
\hline No antenatal visit & 72 & $80 \%$ \\
\hline $\begin{array}{l}3 \text { or more antenatal } \\
\text { visits }\end{array}$ & 10 & $11.1 \%$ \\
\hline $\begin{array}{l}\text { Less than 3 antenatal } \\
\text { visits }\end{array}$ & 08 & $8.9 \%$ \\
\hline
\end{tabular}

A total $80(88.8 \%)$ of patients were referred from outside and only $10(11.11 \%)$ patients had direct admission (Table 7).

\section{Table 7: Distribution of cases as per type} of admission.

\begin{tabular}{|lll|}
\hline Total & $\begin{array}{l}\text { No. of patients } \\
(\mathbf{N = 9 0 )}\end{array}$ & Percentage \\
\hline Referred from outside & 80 & $88.8 \%$ \\
\hline Direct admission & 10 & $11.11 \%$ \\
\hline
\end{tabular}

A total $53.6 \%$ cases were referred from distance of 50$100 \mathrm{~km}, 43.9 \%$ from less than $50 \mathrm{~km}$ and $3.33 \%$ patients were referred from more than $100 \mathrm{~km}$ distance (Table 8).

Table 8: Distance from health care facility.

\begin{tabular}{|lll|}
\hline Distance & No. of cases $(\mathbf{N}=90)$ & Percentage \\
\hline Less than $50 \mathrm{~km}$ & 39 & $43.9 \%$ \\
\hline $50-100 \mathrm{~km}$ & 48 & $53.6 \%$ \\
\hline More than $100 \mathrm{~km}$ & 3 & $3.33 \%$ \\
\hline
\end{tabular}

Table 9: Amount of blood transfusion given.

\begin{tabular}{|lll|}
\hline $\begin{array}{l}\text { No. of units of packed } \\
\text { red cells transfused }\end{array}$ & $\begin{array}{l}\text { No. of patients } \\
(\mathbf{N}=90)\end{array}$ & Percentage \\
\hline 1 unit & 6 & $6.66 \%$ \\
\hline 2 units & 8 & $11.1 \%$ \\
\hline 3units & 5 & $5.55 \%$ \\
\hline 4 or more units & 71 & $78.88 \%$ \\
\hline
\end{tabular}


Table 10: Indications of transfusion.

\begin{tabular}{|lll|}
\hline Indication & Number $(\mathbf{N}=90)$ & Percentage \\
\hline $\begin{array}{l}\text { Anemia without } \\
\text { haemorrhage }\end{array}$ & 36 & $40 \%$ \\
\hline Haemorrhage & 54 & $60 \%$ \\
\hline
\end{tabular}

In this study,78.8\% patients were transfused more than 4 units of packed red cells, $5.55 \%$ required 3 units, $11.1 \% 2$ units and in $6.66 \%$ cases only 1 unit was transfused (Table 9). Haemorrhage was the most common indication for blood transfusion i.e. in $54(60 \%)$ cases and anaemia was indication for blood transfusion in $36(40 \%)$ cases (Table 10).

Maximum number of cases $(42.6 \%)$ of haemorrhage were in immediate postpartum period, $27.7 \%$ cases were in first trimester, $18.5 \%$ were in third trimester and $11.11 \%$ were intrapartum (Table 11).

Table 11: Incidence of hemorrhage according to obstetric period.

\begin{tabular}{|lll|}
\hline Period & No. of cases $(\mathrm{N}=54)$ & Percentage \\
\hline First trimester & 15 & $27.7 \%$ \\
\hline $\begin{array}{l}\text { Antepartum } 3^{\text {rd }} \\
\text { trimester }\end{array}$ & 10 & $18.5 \%$ \\
\hline Intrapartum & 06 & $11.11 \%$ \\
\hline Postpartum & 23 & $42.6 \%$ \\
\hline
\end{tabular}

Out of 54 cases of haemorrhage, $28.4 \%$ cases were of postpartum haemorrhage followed by ruptured ectopic pregnancy $(27.77 \%)$, accidental haemorrhage $(11.11 \%)$, placenta previa $(7.4 \%)$, rupture uterus $(7.4 \%)$, rectus sheath hematoma (5.55\%), placenta accreta (5.55\%), retained placenta $(3.7 \%)$ and inversion uterus $(3.7 \%)$ (Table 12).

Table 12: Causes of haemorrhage.

\begin{tabular}{|lll|}
\hline Cause & $\begin{array}{l}\text { Number } \\
(\mathbf{N = 5 4 )}\end{array}$ & Percentage \\
\hline Ruptured Ectopic & 15 & $27.77 \%$ \\
\hline Atonic PPH & 13 & $24.07 \%$ \\
\hline Accidental hemorrhage & 06 & $11.11 \%$ \\
\hline Traumatic PPH & 02 & $3.70 \%$ \\
\hline Placenta previa & 04 & $7.40 \%$ \\
\hline Rectus sheath hematoma & 03 & $5.55 \%$ \\
\hline Rupture uterus & 04 & $7.40 \%$ \\
\hline Retained placenta & 02 & $3.70 \%$ \\
\hline Placenta accreta & 03 & $5.55 \%$ \\
\hline Inversion uterus & 02 & $3.70 \%$ \\
\hline
\end{tabular}

In this study, 51 interventions were performed in total. Exploration for intractable postpartum haemorrhage was done in $7(13.72 \%)$ cases. 4 cases had laparotomy for ruptured uterus and 15/51 for ruptured ectopic pregnancy. Six cases underwent peripartum hysterectomy. Repair of major genital injuries and manual removal of placenta was done in two cases each. Two cases had repositioning of an inverted uterus. Emergency LSCS was done in 10 $(19.60 \%)$ cases due to severe accidental haemorrhage and major degree placenta previa (Table 13).

Table 13: Management and intervention performed.

\begin{tabular}{|lll|}
\hline Intervention performed & $\begin{array}{l}\text { Number } \\
(\mathbf{N = 9 0 )}\end{array}$ & Percentage \\
\hline Laparotomy due to ectopic & 51 & $29.41 \%$ \\
\hline LSCS I/V/O APH & 10 & $19.60 \%$ \\
\hline Exploration of PPH & 7 & $13.72 \%$ \\
\hline Peripartum hysterectomy & 06 & $11.76 \%$ \\
\hline $\begin{array}{l}\text { Drainage of rectus sheath } \\
\text { hematoma }\end{array}$ & 04 & $7.84 \%$ \\
\hline $\begin{array}{l}\text { Hydrostatic reduction of } \\
\text { inversion uterus }\end{array}$ & 02 & $3.92 \%$ \\
\hline Manual removal of placenta & 02 & $3.92 \%$ \\
\hline $\begin{array}{l}\text { Post LSCS laparotomy due } \\
\text { hemoperitoneum }\end{array}$ & 01 & $1.96 \%$ \\
\hline Repair of rupture uterus & 01 & $1.96 \%$ \\
\hline Balloon tamponade & 03 & $5.88 \%$ \\
\hline Total & 51 & \\
\hline
\end{tabular}

\section{DISCUSSION}

Patients requiring blood transfusion throughout the present study were 90/123 (73.17\%) of maternal near miss cases during study period. According to MNM review pilot project done by Purandare et al, $86 \%$ (227/264) of MNM women received blood transfusions which is almost similar to this study. Yelikar et al also noted that percentage of MNM cases managed by multiple blood component transfusion was around $86 \%$ of cases. ${ }^{9,10}$ In this study, maximum number of cases were between $20-35$ years of age constituting $94.45 \%$ of the cases requiring blood transfusion. Majority of cases requiring blood transfusion were primipara $(52.22 \%)$. $47.77 \%$ cases were in $3^{\text {rd }}$ trimester, $33.33 \%$ were postnatal cases and $16.66 \%$ cases were in first trimester. Maximum cases requiring transfusion belong to low socioeconomic status.

In this study, there was history of no antenatal visit in $80 \%$ cases who required blood transfusion. This finding is similar to study done by Pandya et al, who stated that the incidence of blood transfusion was higher (86\%), in patients who took less than 3 antenatal visits. Lack of antenatal care was noted in $30.7 \%(81 / 264)$ of all MNM cases by Purandre et al. ${ }^{9,11}$ Majority of cases $(88.8 \%)$ were referred in from outside. $78.8 \%$ patients required more than 4 packed red cell transfusions. Haemorrhage was the most common indication $(60 \%)$ for blood transfusion and $40 \%$ cases required blood transfusion because of anaemia. In the study conducted by Pandya et al, $68 \%$ patients required blood because of obstetric hemorrhage and $32 \%$ patients required blood because of anemia of pregnancy. ${ }^{11}$ 
In the present study, out of 54 cases of haemorrhage, postpartum haemorrhage $(28.4 \%)$ was most common cause requiring blood transfusion followed by ruptured ectopic pregnancy $(27.77 \%), \quad$ antepartum haemorrhage( $11.11 \%)$, rupture uterus(7.4\%), rectus sheath hematoma (5.55\%), placenta accrete (5.55\%) and inversion uterus $(3.7 \%)$.

According to a MNM review pilot project by Purandre et al, a detailed break-down of women with haemorrhage showed that most of the critically ill women with haemorrhage were in the postpartum phase $(37 \%), 24 \%$ occurred in late pregnancy, $16 \%$ were associated with ruptured uterus, $19 \%$ occurred in early pregnancy and $4 \%$ were intrapartum. ${ }^{9}$ In this study, 51 interventions were performed. Exploration for intractable postpartum haemorrhage was done in $7(13.72 \%)$ cases. 4 cases had laparotomy for ruptured uterus and 15/51 for ruptured ectopic pregnancy. Six cases under went peripartum hysterectomy. Repair of major genital injuries and manual removal of placenta was done in two cases each. Two cases had repositioning of an inverted uterus. Emergency LSCS was done in $10(19.60 \%)$ cases due to severe accidental haemorrhage and major degree placenta previa.

In MNM review pilot project by Purandre et al, a total of 488 interventions were performed $18.2 \% \quad(48 / 264)$ underwent laparotomy for intractable postpartum haemorrhage, ruptured uterus or ectopic pregnancy, $14.8 \%$ (39/264) had hysterectomy, 4.9\% (13/264) had repair of major genital injuries, $1.1 \%(3 / 264)$ had manual removal of placenta, $0.8 \%(2 / 264)$ had repositioning of an inverted uterus, $1.5 \%$ (4/264) had internal iliac ligation, and $51.9 \%(137 / 264)$ of women underwent other interventions including version, cervical and vaginal tear repair, or drainage of vulval or broad ligament haematoma. $^{9}$

\section{CONCLUSION}

Hemorrhage was the most important direct cause of maternal near miss cases and anemia accounted for indirect cause of maternal morbidity. Prevention and timely treatment of anaemia during antenatal period, early diagnosis of ectopic pregnancy and management can decrease the incidence of MNM. More active participation in term of skilled management of patients at the first referral units is advocated. All major hemorrhage should be reviewed to ensure that the communication chain worked and that there was no delay in provision of blood products.

There should be local protocols for management of massive hemorrhage in obstetrics and familiarity with the local protocol of relevant members of staff (clinicians, midwives, biomedical scientists, porters).
Building the skills of healthcare providers in procedures such as repair of cervical and vaginal tears, resuscitation of adults, medical and surgical management of postpartum haemorrhage, B-lynch suture to manage atonic postpartum haemorrhage, stepwise devascularisation and internal iliac artery ligation and peripartum hysterectomy is advocated.

Funding: No funding sources

Conflict of interest: None declared

Ethical approval: The study was approved by the Institutional Ethics Committee

\section{REFERENCES}

1. Obaid TA. No woman should die giving life. Lancet. 2007;370:1287-8.

2. Pena-Rosas JP, Viteri FE. Effects of routine oral iron supplementation with or without folic acid for women during pregnancy. (Cochrane Review) Cochrane Database Syst Rev. 2012;12:CD004736.

3. Reveiz L, Gyte GM, Cuervo LG. Treatments for irondeficiency anaemia in pregnancy. Cochrane Database Syst Rev. 2007;4:CD003094.

4. Khan KS, Wojdyla D, Say L, Gülmezoglu AM, Van Look PF. WHO analysis of causes of maternal death: A systematic review. Lancet. 2006;367:1066-74.

5. McLintock C, James AH. Obstetric hemorrhage. J Thromb Haemost. 2011;9:1441-51.

6. Cunningham FG, Leveno KJ, Bloom SL, Hauth JC, Rouse DJ, Spong CY, et al. Obstetrical haemorrhage. In: Cunningham FG, Leveno KJ, Bloom SL, Hauth JC, Rouse DJ, Spong CY, et al, editors. Williams Obstetrics. $23^{\text {rd }}$ ed. New York: McGraw-Hill; 2010:757-795.

7. Thomas D, Wee M, Clyburn P, Walker I, Brohi K. Association of anaesthetists of Great Britain and Ireland. Blood transfusion and the anaesthetist: management of massive haemorrhage. Anaesth. 2010;65:1153-61

8. Arulkumaran S, Mavrides E, Penney GC. Aberdeen prevention and management of post-partum haemorrhage. RCOG Green-Top Guideline 52. 2009. Available at: http://www.rcog.org.uk/womenshealth/clinical-guidance/prevention-and-managementssspostpartum-haemorrhage-green-top-52. Accessed on $10^{\text {th }}$ July 2014.

9. Purandare C, Bhardwaj A, Malhotra M, Bhushan H, Chhabra S, Shivkumar P. Maternal near-miss reviews: lessons from a pilot programme in India. BJOG. 2014;121(Suppl. 4):105-11.

10. Yelikar KA, Deshpande SS, Deshmukh SF. Study of severe acute maternal morbidity in tertiary care centre. Int J Scient Stud. 2015;3(5):36-40.

11. Pandya JM, Pandya M, Patel M. Role of blood transfusion in obstetrics. IJSR. 2015;4(5):3-6.

Cite this article as: Mohi MK, Aggarwal S, Khurana SP. Role of blood transfusion in saving mothers. Int J Reprod Contracept Obstet Gynecol 2020;9:2093-7. 